\title{
Ticks on domestic animals in Pernambuco, Northeastern Brazil
}

\author{
Carrapatos em animais domésticos em Pernambuco, Nordeste do Brasil \\ Filipe Dantas-Torres*
}

Dipartimento di Sanità Pubblica e Zootecnia, Facoltà di Medicina Veterinaria, Università degli Studi di Bari

Received June 23, 2008

Accepted August 18, 2009

\begin{abstract}
The objective of this article was to discuss some aspects of ticks associated with domestic animals in the State of Pernambuco, northeastern Brazil, based on a literature review and present new data obtained from recent tick collections carried out in this northeastern Brazilian state. From August 2007 to June 2008, 1,405 ticks were collected and five species were identified: Amblyomma cajennense (Fabricius, 1787), Amblyomma ovale Koch, 1844, Dermacentor nitens Neumann, 1897, Rhipicephalus (Boophilus) microplus (Canestrini, 1887), and Rhipicephalus sanguineus (Latreille, 1806). Dogs from urban areas were found exclusively infested by $R$. sanguineus, whereas dogs from rural areas were found infested by $A$. cajennense, A. ovale, $R$. (B.) microplus, and $R$. sanguineus. The only tick species found on cattle and goats was $R$. (B.) microplus. Horses were found infested by $D$. nitens and at a lesser extent by $A$. cajennense and $R$. (B.) microplus. The only tick species found on donkeys was $D$. nitens. This study confirms the presence of $A$. cajennense in Pernambuco and describes for the first time the presence of $A$. ovale in this state. The medical and veterinary relevance and control of ticks associated with domestic animals in Pernambuco are also briefly discussed.
\end{abstract}

Keywords: Ixodidae, Brazil, taxonomy, domestic animals.

\section{Resumo}

O objetivo desse artigo é discutir alguns aspectos relacionados aos carrapatos que parasitam animais domésticos no Estado de Pernambuco com base numa revisão da literatura e apresentar novos dados obtidos a partir de recentes coletas de carrapatos realizadas nesse estado do nordeste brasileiro. De agosto de 2007 a junho de 2008, 1.405 carrapatos foram coletados e cinco espécies foram identificadas: Amblyomma cajennense (Fabricius, 1787), Amblyomma ovale Koch, 1844, Dermacentor nitens Neumann, 1897, Rhipicephalus (Boophilus) microplus (Canestrini, 1887) e Rhipicephalus sanguineus (Latreille, 1806). Cáes de áreas urbanas foram encontrados infestados exclusivamente por $R$. sanguineus ao passo que cães de áreas rurais foram encontrados parasitados por $A$. cajennense, A. ovale, $R$. (B.) microplus e $R$. sanguineus. A única espécie identificada sobre bovinos e caprinos foi $R$. (B.) microplus. Equinos foram encontrados infestados por $D$. nitens e menos frequentemente por $A$. cajennense e $R$. (B.) microplus. A única espécie de carrapato encontrada sobre asininos foi $D$. nitens. Esse estudo confirma a presença de $A$. cajennense em Pernambuco e registra pela primeira vez a presença de A. ovale nesse estado. A importância médica e veterinária e a situaçáo do controle de carrapatos de animais domésticos em Pernambuco são brevemente discutidas.

Palavras-chave: Ixodidae, Brasil, taxonomia, animais domésticos.

\section{Introduction}

Ticks are known vectors of disease agents to humans and domestic animals (DANTAS-TORRES, 2007, 2008). With respect to pathogen transmission, ticks are among the most important vectors, being comparable only to mosquitoes. It is also noteworthy that ticks still cause significant economic losses to the livestock industry worldwide. These losses, which were estimated

\footnotetext{
*Corresponding author: Filipe Dantas-Torres

Dipartimento di Sanità Pubblica e Zootecnia, Facoltà di Medicina Veterinaria,

Università degli Studi di Bari, Strada Provinciale per Casamassima, km 3, 70010

Valenzano, Bari, Italia; e-mail: filipe@globo.com
}

to be around USD 2 billion per year only in Brazil (GRISI et al., 2002), are mainly a result of blood depletion, transmission of pathogens, and costs of control programs.

Among tick-borne diseases that may affect humans in the Americas, Rocky Mountain spotted fever is probably the most important. This disease is caused by the bacterium Rickettsia rickettsii (Wolbach, 1919) (DANTAS-TORRES, 2007) and tick vectors involved in each disease foci may vary. In Brazil, Amblyomma cajennense (Fabricius, 1787) is a major vector, although other tick species have also been implicated in the transmission cycle 
of $R$. rickettsii (DANTAS-TORRES, 2007). While typically found on horses, $A$. cajennense ticks have a broad host range and can be found on other domestic animals, such as cattle and dogs (ARAGÃO, 1936; GUIMARÃES et al., 2001).

Ticks infesting domestic animals (cat, cattle, chicken, dog, donkey, goat, horse, mule, pig, rabbit, and sheep) have long been studied in Brazil. Domestic animals have been found naturally infested by a number of argasid (Argasidae family) and ixodid (Ixodidae family) tick species. Despite that, there are few reliable records of ticks infesting domestic animals in northeastern Brazilian states, as is the case of Pernambuco. In fact, the literature about ticks infesting domestic animals in Pernambuco is poor (DANTAS-TORRES et al., 2004b) and only few voucher tick specimens have been deposited in reference tick collections. Thus, the aim of the present study was to discuss tick species infesting domestic animals in Pernambuco based on a literature review and present new data obtained from recent tick collections carried out in this northeastern Brazilian state.

\section{Material and Methods}

From August 2007 to June 2008, ticks were collected from domestic animals from different municipalities in Pernambuco (Table 1). Ticks were collected in all geographical areas of Pernambuco; i.e., metropolitan area of Recife (coastal area), Zona da Mata (Atlantic rainforest area), Agreste (middle scrub zone), and Sertão (semi-arid inland area).

Most ticks were casually collected by the author during different field missions carried out at irregular intervals. Ticks sent to the author for identification - most of which collected by veterinarians working in different municipalities of Pernambuco - were also included in this study. As a rule, ticks were collected manually and kept in $70 \%$ ethanol until taxonomic identification using appropriate taxonomic keys (COOLEY, 1946; ARTHUR, 1960; ARAGÃO; FONSECA, 1961; KEIRANS; DURDEN, 1998). Nomenclature of ticks follows Horak et al. (2002).

Voucher tick specimens have been deposited in the following tick collections (accession numbers within brackets): Instituto Butantã, São Paulo, SP, Brazil (IBSP) (9982-9987); Faculdade de Medicina Veterinária e Zootecnia da Universidade de São Paulo, São Paulo, SP, Brazil (CNC) (1313-1316, 1319-1327); Instituto Oswaldo Cruz, Rio de Janeiro, RJ, Brazil (IOC) (0963-0974).

\section{Results}

A total of 1,405 ticks (including males, females, nymphs, and larvae) collected from 85 domestic animals (i.e., cattle, dogs, donkeys, goats, and horses) in Pernambuco were taxonomically studied. Five species were identified: Amblyomma cajennense, Amblyomma ovale Koch, 1844, Dermacentor nitens Neumann, 1897 (formerly Anocentor nitens), Rhipicephalus (Boophilus) microplus (Canestrini, 1887) (formerly Boophilus microplus), and Rhipicephalus sanguineus (Latreille, 1806). Co-infestation by more than one tick species was observed in $14(16.7 \%)$ animals. For convenience' sake, detailed information regarding examined material is presented in Table 2 .

\section{Discussion}

The tick species found on domestic animals in Pernambuco are those commonly found in other Brazilian states (ARAGÁO, 1936; LABRUNA et al., 2000; GUIMARÃES et al., 2001; GUERRA; BRITO, 2004).

\section{Ticks infesting cats and dogs}

There is no record of tick infestation on cats in Pernambuco. Cats are rarely found infested by ticks (ARAGĀO, 1936; GUIMARÃES et al., 2001; SILVA et al., 2007) and this is in part due to their hygiene habits that favor the removal of ectoparasites. Sometimes ticks can attach in areas of difficult access (e.g., head) for cats to remove them (SILVA et al., 2007), thus favoring parasitism.

In urban areas of Pernambuco, dogs have typically been found infested by $R$. sanguineus ticks (DANTAS-TORRES et al., 2004b). In highly infested environments, $R$. sanguineus ticks can be found on carpets, walls, and furniture and they can incidentally parasitize other hosts, including humans (DANTAS-TORRES et al., 2006).

In rural areas of Pernambuco, dogs have been found infested by $R$. sanguineus and occasionally by other tick species, including A. cajennense, $A$. ovale, and $R$. (B.) microplus, as shown in Table 2 . Among these, $A$. ovale and $R$. sanguineus appear to be the most common ticks infesting dogs in some rural areas of Pernambuco (F.D.-T., unpublished data). The parasitism by ticks other than $R$. sanguineus in dogs is particularly usual in farms where dogs live in close contact with livestock and also in dogs living near forested areas. However, previous reports of D. nitens and Amblyomma fuscum (Neumann, 1907) on dogs in Pernambuco (ROCHA, 1985; see DANTAS-TORRES et al., 2004) could not be confirmed. To date, the only reliable records of A. fuscum in Pernambuco were adults collected from red-tailed boas (Boa constrictor Linnaeus, 1758) (DANTAS-TORRES et al., 2008) and nymphs collected from small mammals and reared to the adult stage (MARTINS et al., in press).

\section{Ticks infesting cattle, goats, and sheep}

In the present study, the only tick species found on cattle and goats was $R$. (B.) microplus and no tick was found on sheep. Aragáo (1936) reported the presence of $R$. (B.) microplus in Recife, Água Preta, and Tapera (Moreno?), although without further data about tick developmental stages or hosts. Working in the municipality of Garanhuns, Rocha (1985) identified A. cajennense, D. nitens, and $R$. (B.) microplus on cattle and D. nitens and $R$. (B.) microplus on goats. Unfortunately, no voucher tick specimens from Rocha study are available in reference collections. Thus, further collections of ticks on cattle from Garanhuns should be carried out to confirm these findings. In our hands, $R$. (B.) microplus was the only species found on cattle in Garanhuns.

It is well known that $R$. (B.) microplus ticks can occasionally be found on hosts other than cattle (ARAGÃO, 1936; GUIMARÃES et al., 2001). But although relatively common in certain areas, the infestation by $R$. (B.) microplus ticks on certain hosts (e.g., cats, dogs, chickens, and rabbits) is usually accidental. 
Table 1. Study area.

\begin{tabular}{|c|c|c|c|c|c|}
\hline Geographical region & Municipality & Latitude & Longitude & Altitude (m) & Territory $\left(\mathbf{k m}^{2}\right)$ \\
\hline \multirow{9}{*}{$\begin{array}{l}\text { Agreste } \\
\text { (middle scrub zone) }\end{array}$} & Agrestina & $08^{\circ} 27^{\prime} 29^{\prime \prime}$ & $35^{\circ} 56^{\prime} 41^{\prime \prime}$ & 427 & 201 \\
\hline & Bezerros & $08^{\circ} 14^{\prime} 00^{\prime \prime}$ & $35^{\circ} 47^{\prime} 49^{\prime \prime}$ & 470 & 493 \\
\hline & Feira Nova & $07^{\circ} 57^{\prime} 03^{\prime \prime}$ & $35^{\circ} 23^{\prime} 21^{\prime \prime}$ & 154 & 108 \\
\hline & Garanhuns & $08^{\circ} 53^{\prime} 25^{\prime \prime}$ & $36^{\circ} 29^{\prime} 34^{\prime \prime}$ & 842 & 472 \\
\hline & Gravatá & $08^{\circ} 12^{\prime} 04^{\prime \prime}$ & $35^{\circ} 33^{\prime} 53^{\prime \prime}$ & 447 & 513 \\
\hline & Limoeiro & $07^{\circ} 52^{\prime} 29^{\prime \prime}$ & $35^{\circ} 27^{\prime} 01^{\prime \prime}$ & 138 & 270 \\
\hline & Passira & $07^{\circ} 59^{\prime} 42^{\prime \prime}$ & $35^{\circ} 34^{\prime} 50^{\prime \prime}$ & 176 & 330 \\
\hline & Sairé & $08^{\circ} 19^{\prime} 39^{\prime \prime}$ & $35^{\circ} 42^{\prime} 20^{\prime \prime}$ & 663 & 195 \\
\hline & São Vicente Férrer & $07^{\circ} 35^{\prime} 28^{\prime \prime}$ & $35^{\circ} 29^{\prime} 29^{\prime \prime}$ & 419 & 110 \\
\hline \multirow{5}{*}{$\begin{array}{l}\text { Metropolitan area of Recife } \\
\text { (coastal area) }\end{array}$} & Camaragibe & $08^{\circ} 01^{\prime} 18^{\prime \prime}$ & $34^{\circ} 58^{\prime} 52^{\prime \prime}$ & 55 & 55 \\
\hline & Ipojuca & $08^{\circ} 23^{\prime} 56^{\prime \prime}$ & $35^{\circ} 03^{\prime} 50^{\prime \prime}$ & 10 & 527 \\
\hline & Olinda & $08^{\circ} 00^{\prime} 32^{\prime \prime}$ & $34^{\circ} 51^{\prime} 19^{\prime \prime}$ & 16 & 44 \\
\hline & Paulista & $07^{\circ} 56^{\prime} 27^{\prime \prime}$ & $34^{\circ} 52^{\prime} 23^{\prime \prime}$ & 13 & 94 \\
\hline & Recife & $08^{\circ} 03^{\prime} 14^{\prime \prime}$ & $34^{\circ} 52^{\prime} 52^{\prime \prime}$ & 4 & 217 \\
\hline \multirow{4}{*}{$\begin{array}{l}\text { Zona da Mata } \\
\text { (Atlantic rainforest area) }\end{array}$} & Amaraji & $08^{\circ} 22^{\prime} 59^{\prime \prime}$ & $35^{\circ} 27^{\prime} 09^{\prime \prime}$ & 289 & 235 \\
\hline & Glória do Goitá & $08^{\circ} 00^{\prime} 06^{\prime \prime}$ & $35^{\circ} 17^{\prime} 34^{\prime \prime}$ & 158 & 231 \\
\hline & Paudalho & $07^{\circ} 53^{\prime} 48^{\prime \prime}$ & $35^{\circ} 10^{\prime} 47^{\prime \prime}$ & 69 & 278 \\
\hline & Vicência & $07^{\circ} 39^{\prime} 25^{\prime \prime}$ & $35^{\circ} 19^{\prime} 36^{\prime \prime}$ & 119 & 231 \\
\hline Sertão (semi-arid inland area) & Petrolina & $09^{\circ} 23^{\prime} 55^{\prime \prime}$ & $40^{\circ} 30^{\prime} 03^{\prime \prime}$ & 376 & 4,559 \\
\hline
\end{tabular}

\section{Ticks infesting donkeys and horses}

Horses were found infested by $D$. nitens and occasionally by A. cajennense and $R$. (B.) microplus. The horses found infested by $A$. cajennense were co-infested by $D$. nitens. Overall, these results are in agreement with Rocha's early findings (1985) in Garanhuns. Additionally, Silva (1989) found $R$. sanguineus on horses in Garanhuns. However, as no voucher specimens were deposited in reference collections, the infestation by $R$. sanguineus on horses in Pernambuco needs confirmation.

Donkeys were infested exclusively by $D$. nitens. Rocha (1895) reported the presence of $D$. nitens and $R$. (B.) microplus ticks infesting donkeys and mules in Garanhuns.

\section{Ticks infesting chickens, pigs, and rabbits}

In the present study, no ticks were found on chickens, pigs, and rabbits. During the 1930s, Aragão (1936) reported the presence of Argas miniatus Koch, 1844 and Haemaphysalis leporispalustris (Packard, 1869) in Pernambuco. Except for Aragáo report, there is no record of the presence of these tick species in this state. Considering that $A$. miniatus and $H$. leporispalustris have been found in most Brazilian states (ARAGÃO, 1936; GUIMARÁES et al., 2001), it should be expected that both species are present in Pernambuco. However, further research to confirm the presence of $A$. miniatus and $H$. leporispalustris in Pernambuco are needed.

To the author's knowledge, there is no record of tick infestations on pigs in Pernambuco. In other Brazilian states, pigs have occasionally been found infested by Amblyomma aureolatum (Pallas, 1772), A. cajennense, Amblyomma naponense Packard, 1869, Amblyomma oblongoguttatum Koch, 1844, A. ovale, Amblyomma scalpturatum Neumann, 1906, and $R$. (B.) microplus (ARAGÃO, 1936; GUIMARÁES et al., 2001; LABRUNA et al., 2002). Of note, in a rural property where $A$. ovale ticks were found on two dogs, there were some pigs but they were free of ticks.

\section{Notes on the ecology of ticks of domestic animals in Pernambuco}

The present study revealed that $A$. cajennense ticks occur in all areas of Pernambuco, except in the semi-arid inland area. This area is typically hot and dry, which might be unsuitable for $A$. cajennense ticks (CHACÓN et al., 2003). However, the climate of some municipalities (e.g., Triunfo) seems to favor the development of $A$. cajennense. Therefore, further studies are expected to reveal the presence of $A$. cajennense in this area. This tick is known to have low host-specificity and high affinity for humans (DANTAS-TORRES, 2007). The person in charge of the horse found infested by $A$. cajennense in Amaraji (Atlantic rainforest area) informed that her children are usually bitten by ticks, particularly when they are undertaking activities in a remnant of the Atlantic rainforest located near her property.

Amblyomma ovale ticks are currently known to occur only in the middle scrub zone of Pernambuco. This tick is a common ectoparasite of dogs from the municipality of São Vicente Férrer (F.D.-T., unpublished data). Considering the physical geography of this municipality, $A$. ovale ticks are likely to be present also in the Atlantic rainforest area and possibly in the coastal area.

Dermacentor nitens ticks are common in all geographical areas of Pernambuco (ROCHA, 1985; SILVA, 1989; FAUSTINO et al., 2005). An exception is the municipality of Petrolina where infestation by $D$. nitens on horses occurs but is apparently less 
Table 2. Detailed data on ticks $(n=1,405)$ collected from domestic animals $(n=85)$ in Pernambuco, from August 2007 to June 2008.

\begin{tabular}{|c|c|c|c|c|}
\hline No & Specimens & Host & Municipality & Date \\
\hline 1 & $1 \mathrm{M}$ of $R$. sanguineus & C. familiaris & Olinda & August 2007 \\
\hline 2 & $5 \mathrm{M}, 2 \mathrm{~F}$ and $1 \mathrm{~N}$ of $R$. sanguineus & C. familiaris & Recife & August 2007 \\
\hline 3 & $1 \mathrm{M}$ and $1 \mathrm{~F}$ of $R$. sanguineus & C. familiaris & Agrestina & October 2007 \\
\hline 4 & $7 \mathrm{~F}$ of $R .(B$.$) microplus$ & B. taurus & Agrestina & October 2007 \\
\hline 5 & $1 \mathrm{~F}$ of $R .(B$.$) microplus$ & B. taurus & Agrestina & October 2007 \\
\hline 6 & $8 \mathrm{~F}$ of $R .(B$.$) microplus$ & B. taurus & Agrestina & October 2007 \\
\hline 7 & $5 \mathrm{M}$ and $10 \mathrm{~F}$ of $R$. sanguineus & C. familiaris & Amaraji & November 2007 \\
\hline 8 & $3 \mathrm{~N}$ of $A$. cajennense; $1 \mathrm{M}$ of $R$. sanguineus & C. familiaris & Amaraji & November 2007 \\
\hline 9 & $1 \mathrm{M}$ and $2 \mathrm{~F}$ of $R$. sanguineus & C. familiaris & Passira & November 2007 \\
\hline 10 & $2 \mathrm{M}, 2 \mathrm{~F}$ and $1 \mathrm{~N}$ of $R$. sanguineus & C. familiaris & Passira & November 2007 \\
\hline 11 & $5 \mathrm{M}, 2 \mathrm{~F}, 5 \mathrm{~N}$ and $5 \mathrm{~L}$ of $R$. sanguineus & C. familiaris & Petrolina & November 2007 \\
\hline 12 & $3 \mathrm{M}, 2 \mathrm{~F}$ and $7 \mathrm{~N}$ of $R$. sanguineus & C. familiaris & Recife & November 2007 \\
\hline 13 & $6 \mathrm{M}$ and $8 \mathrm{~F}$ of $R$. sanguineus & C. familiaris & Vicência & November 2007 \\
\hline 14 & $1 \mathrm{~F}$ of $R .(B$.$) microplus$ & C. hircus & Passira & November 2007 \\
\hline 15 & $1 \mathrm{M}$ and $5 \mathrm{~F}$ of $R$. (B.) microplus & C. hircus & Passira & November 2007 \\
\hline 16 & $13 \mathrm{M}, 5 \mathrm{~F}$ and $6 \mathrm{~N}$ of $A$. cajennense; $1 \mathrm{~F}, 10 \mathrm{~N}$ and $1 \mathrm{~L}$ of $D$. nitens & E. caballus & Amaraji & November 2007 \\
\hline 17 & $2 \mathrm{~N}$ of $R$. sanguineus & C. familiaris & Petrolina & December 2007 \\
\hline 18 & $1 \mathrm{M}$ and $5 \mathrm{~F}$ of $R$. sanguineus & C. familiaris & Petrolina & December 2007 \\
\hline 19 & $10 \mathrm{M}$ and $2 \mathrm{~F}$ of $R$. sanguineus & C. familiaris & Petrolina & December 2007 \\
\hline 20 & $1 \mathrm{M}$ of $R$. sanguineus & C. familiaris & Glória de Goitá & December 2007 \\
\hline 21 & $4 \mathrm{~F}$ and $1 \mathrm{~N}$ of $R$. (B.) microplus & B. indicus & Vicência & December 2007 \\
\hline 22 & $1 \mathrm{M}, 6 \mathrm{~F}$ and $1 \mathrm{~N}$ of $R .(B$.$) microplus$ & B. taurus & Vicência & December 2007 \\
\hline 23 & $20 \mathrm{M}, 30 \mathrm{~F}, 23 \mathrm{~N}$ and $3 \mathrm{~L}$ of $D$. nitens & E. caballus & Vicência & December 2007 \\
\hline 24 & $17 \mathrm{M}, 9 \mathrm{~F}, 11 \mathrm{~N}$ and $2 \mathrm{~L}$ of $D$. nitens & E. asinus & Vicência & December 2007 \\
\hline 25 & $3 \mathrm{M}, 2 \mathrm{~F}, 2 \mathrm{~N}$ and $1 \mathrm{~L}$ of $D$. nitens & E. asinus & Vicência & December 2007 \\
\hline 26 & $4 \mathrm{~F}$ and $1 \mathrm{~N}$ of $D$. nitens & E. caballus & Camaragibe & December 2007 \\
\hline 27 & $1 \mathrm{M}, 18 \mathrm{~N}$ and $2 \mathrm{~L}$ of $D$. nitens & E. caballus & Gravatá & December 2007 \\
\hline 28 & $3 \mathrm{M}, 13 \mathrm{~N}$ and $1 \mathrm{~L}$ of $D$. nitens & E. caballus & Gravatá & December 2007 \\
\hline 29 & $1 \mathrm{M}, 1 \mathrm{~F}, 54 \mathrm{~N}$ and $12 \mathrm{~L}$ of $D$. nitens; $3 \mathrm{~N}$ of $R$. (B.) microplus & E. caballus & Gravatá & December 2007 \\
\hline 30 & $2 \mathrm{M}, 5 \mathrm{~F}, 2 \mathrm{~N}$ and $1 \mathrm{~L}$ of $D$. nitens; $1 \mathrm{M}$ of $A$. cajennense & E. caballus & Gravatá & December 2007 \\
\hline 31 & $2 \mathrm{M}$ and $2 \mathrm{~F}$ of $D$. nitens & E. caballus & Gravatá & December 2007 \\
\hline 32 & $6 \mathrm{~F}$ of $D$. nitens & E. caballus & Gravatá & December 2007 \\
\hline 33 & $3 \mathrm{~F}$ of $D$. nitens & E. caballus & Gravatá & December 2007 \\
\hline 34 & $3 \mathrm{~F}$ of $D$. nitens; $2 \mathrm{~F}$ of $R .(B$.$) microplus$ & E. caballus & Glória do Goitá & December 2007 \\
\hline 35 & $14 \mathrm{M}, 28 \mathrm{~F}, 21 \mathrm{~N}$ and $6 \mathrm{~L}$ of $D$. nitens & E. caballus & Glória do Goitá & December 2007 \\
\hline 36 & $4 \mathrm{M}$ and $5 \mathrm{~F}$ of $D$. nitens & E. caballus & Glória do Goitá & December 2007 \\
\hline 37 & $2 \mathrm{M}$ and $12 \mathrm{~F}$ of $D$. nitens & E. caballus & Glória do Goitá & December 2007 \\
\hline 38 & $5 \mathrm{M}, 5 \mathrm{~F}, 5 \mathrm{~N}$ and $1 \mathrm{~L}$ of $D$. nitens; $2 \mathrm{M}$ of $R$. (B.) microplus & E. caballus & Glória do Goitá & December 2007 \\
\hline 39 & $1 \mathrm{M}$ of $R$. sanguineus; $1 \mathrm{M}$ and $3 \mathrm{~F}$ of $R$. (B.) microplus & C. familiaris & Feira Nova & January 2008 \\
\hline 40 & $7 \mathrm{M}$ and $5 \mathrm{~F}$ of $R$. sanguineus & C. familiaris & Paudalho & January 2008 \\
\hline 41 & $31 \mathrm{M}$ and $31 \mathrm{~F}$ of $R$. sanguineus & C. familiaris & Paudalho & January 2008 \\
\hline 42 & $34 \mathrm{M}, 30 \mathrm{~F}$, and $2 \mathrm{~N}$ of $R$. sanguineus & C. familiaris & Paudalho & January 2008 \\
\hline 43 & $2 \mathrm{M}$ of $R$. sanguineus & C. familiaris & São Vicente Férrer & January 2008 \\
\hline 44 & $3 \mathrm{M}$ and $6 \mathrm{~F}$ of $R$. sanguineus & C. familiaris & Passira & January 2008 \\
\hline 45 & $9 \mathrm{M}$ and $21 \mathrm{~F}$ of $R$. sanguineus & C. familiaris & Limoeiro & January 2008 \\
\hline 46 & $1 \mathrm{M}, 3 \mathrm{~F}$ and $2 \mathrm{~N}$ of $R .(B$.$) microplus$ & B. indicus & Garanhuns & January 2008 \\
\hline 47 & $2 \mathrm{M}$ and $6 \mathrm{~F}$ of $R .(B$.$) microplus$ & B. taurus & Garanhuns & January 2008 \\
\hline 48 & $9 \mathrm{~F}$ of $R .(B$.$) microplus$ & B. taurus & Garanhuns & January 2008 \\
\hline 49 & $9 \mathrm{~F}$ of $R .(B$.$) microplus$ & B. indicus & Garanhuns & January 2008 \\
\hline 50 & $4 \mathrm{M}$ and $7 \mathrm{~F}$ of $R$. (B.) microplus & B. taurus & Garanhuns & January 2008 \\
\hline 51 & $1 \mathrm{M}$ and $7 \mathrm{~F}$ of $R .(B$.$) microplus$ & B. indicus & Garanhuns & January 2008 \\
\hline 52 & $3 \mathrm{~F}$ of $R .(B$.$) microplus$ & B. taurus & Garanhuns & January 2008 \\
\hline 53 & $10 \mathrm{~N}$ and $5 \mathrm{~L}$ of $D$. nitens & E. caballus & Ipojuca & January 2008 \\
\hline
\end{tabular}

Abbreviations: M, males; F, females; N, nymphs; L, larvae. 
Table 2. Continued...

\begin{tabular}{|c|c|c|c|c|}
\hline No & Specimens & Host & Municipality & Date \\
\hline 54 & $1 \mathrm{M}, 5 \mathrm{~F}, 5 \mathrm{~N}$ and $1 \mathrm{~L}$ of $D$. nitens & E. caballus & Feira Nova & January 2008 \\
\hline 55 & $18 \mathrm{~N}$ and $3 \mathrm{~L}$ of $D$. nitens & E. caballus & Feira Nova & January 2008 \\
\hline 56 & $1 \mathrm{~N}$ of $D$. nitens & E. caballus & Petrolina & January 2008 \\
\hline 58 & $5 \mathrm{M}, 9 \mathrm{~F}$ and $2 \mathrm{~N}$ of $D$. nitens & E. caballus & Gravatá & January 2008 \\
\hline 59 & $6 \mathrm{M}$ and $5 \mathrm{~F}$ of $D$. nitens & E. caballus & Gravatá & January 2008 \\
\hline 62 & $5 \mathrm{M}$ and $4 \mathrm{~F}$ of $D$. nitens; $1 \mathrm{M}$ of $R$. (B.) microplus & E. caballus & Sairé & January 2008 \\
\hline 63 & $\begin{array}{l}3 \mathrm{M}, 3 \mathrm{~F}, 35 \mathrm{~N} \text { and } 35 \mathrm{~L} \text { of } D . \text { nitens; } 1 \mathrm{M} \text { of } A \text {. cajennense; } 8 \mathrm{~N} \text { of } \\
\text { R. (B.) microplus }\end{array}$ & E. caballus & Sairé & January 2008 \\
\hline 64 & $2 \mathrm{M}, 5 \mathrm{~F}, 9 \mathrm{~N}$ and $4 \mathrm{~L}$ of $D$. nitens & E. caballus & Sairé & January 2008 \\
\hline 65 & $1 \mathrm{M}$ and $3 \mathrm{~F}$ of $D$. nitens & E. caballus & Sairé & January 2008 \\
\hline 69 & $2 \mathrm{M}$ and $2 \mathrm{~F}$ of $D$. nitens & E. asinus & Limoeiro & January 2008 \\
\hline 70 & $1 \mathrm{M}$ and $1 \mathrm{~F}$ of $R$. sanguineus & C. familiaris & Feira Nova & February 2008 \\
\hline 71 & $72 \mathrm{M}$ and $65 \mathrm{~F}$ of $R$. sanguineus & C. familiaris & Olinda & February 2008 \\
\hline 72 & $12 \mathrm{~N}$ of $R$. sanguineus & C. familiaris & Olinda & February 2008 \\
\hline 73 & $5 \mathrm{M}$ and $15 \mathrm{~F}$ of $R$. sanguineus & C. familiaris & Passira & February 2008 \\
\hline 74 & $10 \mathrm{M}$ and $6 \mathrm{~F}$ of $R$. sanguineus & C. familiaris & Paulista & February 2008 \\
\hline 75 & $2 \mathrm{M}$ and $1 \mathrm{~F}$ of $D$. nitens & E. caballus & Bezerros & February 2008 \\
\hline 76 & $5 \mathrm{~F}$ of $D$. nitens & E. caballus & Bezerros & February 2008 \\
\hline 77 & $2 \mathrm{M}$ and $5 \mathrm{~F}$ of $D$. nitens & E. caballus & Feira Nova & February 2008 \\
\hline 78 & $4 \mathrm{M}, 5 \mathrm{~F}$ and $1 \mathrm{~N}$ of $R$. sanguineus & C. familiaris & Recife & March 2008 \\
\hline
\end{tabular}

Abbreviations: M, males; F, females; N, nymphs; L, larvae.

common (F.D.-T, personal observations). The climate of Petrolina is probably unsuitable for the development and survival of $D$. nitens. Its climate is characterized by high temperatures associated with low relative humidity and low precipitation. The mean annual relative humidity is about $65 \%$, but during the dry season it may be as low as $50 \%$ and the mean annual rainfall is less than $800 \mathrm{~mm}$ (SILVA, 2004). It is known that low relative humidity $(<50 \%)$ greatly affects both egg hatching and larval survival rates of $D$. nitens ticks (GUIMARÁES DA SILVA et al., 1997; SUZUKI et al., 1999; FAUSTINO et al., 2005).

Rhipicephalus (Boophilus) microplus ticks are found infesting cattle in all geographical areas of Pernambuco. This is expected because $R$. (B.) microplus is historically well established in the Brazilian territory (ARAGÃO, 1936) and because the climate of Pernambuco is suitable for its development and survival. In the present study, $R$. (B.) microplus was found not only on cattle but also on a dog, goats, and horses.

Rhipicephalus sanguineus ticks have been found in virtually all geographical areas of Pernambuco. They are common anywhere, from Recife (far east) to Petrolina (far west). This is expected due to the fact that $R$. sanguineus is differentially adapted to live in both humid and dry environments (YODER et al., 2006). Interestingly, the intensity of parasitism by $R$. sanguineus on dogs living in rural areas is lower than in urban areas (F.D.-T, personal observations). The explanation for this is not yet clear, but it is likely to be due to a combination of factors, including host density and climate (temperature and relative humidity).

Co-infestations by more than one tick species were commonly observed in the present study. Dogs were found infested simultaneously by $A$. ovale plus $R$. sanguineus, $A$. cajennense plus $R$. sanguineus, and $R$. (B.) microplus plus $R$. sanguineus. Horses were found co-infested by $A$. cajennense plus $D$. nitens and $D$. nitens plus $R$. (B.) microplus. Additionally, a horse was found infested by three tick species (i.e., $A$. cajennense, $D$. nitens and $R$. (B.) microplus). In rural properties where domestic animals (e.g., dogs, cattle and horses) live in close contact the occurrence of co-infestation might be common. 


\section{Medical and veterinary significance of ticks of domestic animals in Pernambuco}

All four tick species found on domestic animals in Pernambuco are known vectors of pathogens of veterinary significance. Incidentally, they can parasitize human beings and act as vectors of major human disease agents (GUGLIELMONE et al., 2006). For instance, $A$. cajennense is the main vector of $R$. rickettsii in Brazil (DANTAS-TORRES, 2007) and R. sanguineus has been implicated in the transmission of a large list of pathogens, including R. rickettsii, Babesia canis vogeli Reichenow, 1937 and Babesia gibsoni (Patton, 1910) (DANTAS-TORRES; FIGUEREDO, 2006; DANTAS-TORRES, 2007, 2008). Additionally, there has been speculation on the role of $R$. sanguineus as a potential vector of Leishmania infantum Nicolle, 1908 (=Leishmania chagasi Cunha \& Chagas, 1937) in Brazil (COUTINHO et al., 2005), including in Pernambuco (SILVA et al., 2007), but it requires further investigation.

Tick-borne pathogens have long been recognized in Pernambuco (ALECRIM et al., 1983; DANTAS-TORRES et al., 2004a; ARAÚJO et al., 2005; DANTAS-TORRES; FIGUEREDO, 2006), although little information is currently available about tick-borne diseases, their distribution, risk factors, and impact on livestock industry in this state. For example, a suspected case of human babesiosis was documented in Pernambuco during the early 1980s (ALECRIM et al., 1983) and, so far, no further data on human babesiosis in Pernambuco has been obtained and little is known of tick species infesting humans in this state. Cases of human parasitism by $R$. sanguineus ticks have been recorded in Pernambuco (DANTAS-TORRES et al., 2006) and human parasitism by Amblyomma larvae is not rare, particularly in people entering into remnants of Atlantic rainforest (F.D.-T, unpublished data).

\section{Tick control in Pernambuco and research needs}

The status of tick control in Pernambuco is largely unknown. The control of $R$. (B.) microplus has been studied in properties located in the Atlantic rainforest area and the middle scrub zone of Pernambuco (SANTANA et al., 2001b). It was found that 85.7\% of cattle managers did not know "what acaricide resistance means". The active compounds most commonly used in the surveyed properties were cypermethrin, amitraz, and ivermectin. Acaricide spraying is the most commonly used method in both areas.

The control of $R$. sanguineus is commonly carried out using fipronil, selamectine, pyrethroids (e.g., cypermethrin and deltamethrin), and amitraz. Spray, spot-on or pour-on formulations and impregnated-collars are often used by dog owners in the metropolitan area of Recife, but not in rural areas. Under certain circumstances (e.g., in highly infested domiciles), the use of acaricides on the environment has been recommended (F.D.-T, personal observations).

Acaricide resistance in ticks has been described in Pernambuco (SANTANA et al., 2001a, 2001b), although the burden of acaricide resistance on the livestock industry in this state has not been systematically evaluated. Resistance is in part a result of the uncontrolled use of acaricides, as discussed elsewhere (SANTANA et al., 2001b). Alternatives for tick control, such as use of medicinal plants, have been studied in Pernambuco and the results are promising (FARIAS et al., 2007).

During the 1930s, Aragáo (1936) reported the presence of A. aureolatum and Amblyomma parvum Aragão, 1908 in Pernambuco, but without further data on ticks or hosts. During recent decades, there were no records of $A$. aureolatum and A. parvum in Pernambuco. Thus, the presence of both species in this state needs confirmation. Also, further studies about ticks and tick-borne diseases in Pernambuco are urgently needed. The present study definitely confirms the presence of $A$. cajennense in Pernambuco and raises some questions about the local risk of transmission of tick-borne diseases, such as Rocky Mountain spotted fever. Further studies to assess the current distribution and ecology of $A$. cajennense ticks in Pernambuco are recommended. Additionally, it is crucial to determine whether these ticks are infected by pathogens of medical and veterinary significance, particularly by $R$. rickettsii. This could provide new insights about the ecology of ticks and the pathogens they transmit.

\section{Acknowledgments}

Thanks to my colleagues (Andresa C. B. de Oliveira, Anne G. S. S. Campos, Assis B. Nunes, Danniele de G. Barboza, Fernando J. da Silva, Ana K. de A. Soares, Karla P. de O. Luna, Maria I. A. Cavalcanti, Mineo Nakazawa, Raquel Vasconcelos, and Vitor N. Maia) for kindly sending me tick specimens for identification. Thanks also to the Coordenação de Aperfeiçoamento de Pessoal de Nivel Superior (CAPES) for a PhD scholarship.

\section{References}

ALECRIM, I. et al. Registro do primeiro caso de infecção humana por Babesia spp. no Brasil. Revista de Patologia Tropical, v. 12, n. 1, p.11-29, 1983.

ARAGÃO, H. Ixodidas brasileiros e de alguns paizes limitrophes. Memórias do Instituto Oswaldo Cruz, v. 31, n. 4, p. 759-843, 1936.

ARAGÃO, H.; FONSECA, F. Notas de Ixodologia VIII. Lista e chave para representantes da fauna Ixodológica Brasileira. Memórias do Instituto Oswaldo Cruz, v. 59, n. 2, p. 115-129, 1961.

ARAÚJO, F. R. et al. Development of enzyme-linked immunosorbent assays based on recombinant MSP1a and MSP2 of Anaplasma marginale. Memórias do Instituto Oswaldo Cruz, v. 100, n. 7, p. 765-769, 2005.

ARTHUR, D. R. Ticks: A monograph of the Ixodoidea. Part V. On the genera Dermacentor, Anocentor, Cosmiomma, Boophilus and Margaropus. London: Cambridge University Press, 1960. 279 p.

CHACÓN, S. C. et al. Efeito de três temperaturas constantes sobre a fase não parasitária de Amblyomma cajennense (Fabricius, 1787) (Acari: Ixodidae). Revista Brasileira de Parasitologia Veterinária, v. 12, n. 1, p. 13-20, 2003.

COOLEY, R. A. The genera Boophilus, Rhipicephalus, and Haemaphysalis (Ixodidae) of the New World. National Institute of Health Bulletin, v. 187 , p. 1-54, 1946. 
COUTINHO, M. T. et al. Participation of Rhipicephalus sanguineus (Acari: Ixodidae) in the epidemiology of canine visceral leishmaniasis. Veterinary Parasitology, v. 128, n. 1/2, p. 149-155, 2005.

DANTAS-TORRES, F. Rocky Mountain spotted fever. Lancet Infectious Diseases, v. 7, n. 11, p. 724-732, 2007.

DANTAS-TORRES, F. The brown dog tick, Rhipicephalus sanguineus (Latreille, 1806) (Acari: Ixodidae): from taxonomy to control. Veterinary Parasitology, v. 152, n. 3/4, p. 173-185, 2008.

DANTAS-TORRES, F.; FAUSTINO, M. A. G.; ALVES, L. C. Coinfection by Anaplasma platys, Babesia canis and Ehrlichia canis in a dog from Recife, Pernambuco, Brazil: case report. Revista Brasileira de Parasitologia Veterinária, v. 13, suplemento 1, p. 371, 2004 a.

DANTAS-TORRES, F.; FIGUEREDO, L. A. Canine babesiosis: A Brazilian perspective. Veterinary Parasitology, v. 141, n. 3/4, p. 197-203, 2006.

DANTAS-TORRES, F; FIGUEREDO, L. A.; BRANDÃO-FILHO, S. P. Rhipicephalus sanguineus (Acari: Ixodidae), the brown dog tick, parasitizing humans in Brazil. Revista da Sociedade Brasileira de Medicina Tropical, v. 39, n. 1, p. 64-67, 2006.

DANTAS-TORRES, F.; FIGUEREDO, L. A.; FAUSTINO, M. A. G. Ectoparasitos de cães provenientes de alguns municípios da região metropolitana do Recife, Pernambuco, Brasil. Revista Brasileira de Parasitologia Veterinária, v. 13, n. 4, p. 151-154, 2004 b.

DANTAS-TORRES, F. et al. Ticks infesting amphibians and reptiles in Pernambuco, Northeastern Brazil. Revista Brasileira de Parasitologia Veterinária, v. 17, n. 4, p. 218-221, 2008.

FARIAS, M. P. O. et al. Eficácia in vitro do óleo da Carapa guianensis Aubl. (andiroba) no controle de Boophilus microplus (Acari: Ixodidae). Revista Brasileira de Plantas Medicinais, v. 9, n. 4, p. 68-71, 2007.

FAUSTINO, M. A. G. et al. Estudo comparativo de dados bioecológicos da fase não parasitária de Anocentor nitens (Acari: Ixodidae) (Neumann, 1897) em dois ambientes experimentais no Recife - PE. Ciência Veterinária nos Trópicos, v. 8, n. 1, p. 43-52, 2005.

GRISI, L. et al. Impacto econômico das principais ectoparasitoses em bovinos no Brasil. A Hora Veterinária, v. 21, n. 125, p. 8-10, 2002.

GUERRA, R. M. S. N. C.; BRITO, D. R. B. Ixodofauna de mamíferos domésticos da Ilha de São Luís, estado do Maranhão, Brasil. Entomologia y Vectores, v. 11, n. 3, p. 435-444, 2004.

GUGLIELMONE, A. A. et al. Ticks (Ixodidae) on humans in South America. Experimental and Applied Acarology, v. 40, n. 2, p. 83-100, 2006.

GUIMARÁES DA SILVA, C. L. et al. Efeito de diferentes teores de umidade sobre a biologia da fase de vida livre de Anocentor nitens (Neumann) Schulze, 1937 (Acari: Ixodidae). Revista Brasileira de Parasitologia Veterinária, v. 6, n. 1, p. 29-32, 1997.

GUIMARĀES, J.H.; TUCCI, E.C.; BARROS-BATTESTI, D.M. Ectoparasitos de importância veterinária. São Paulo: Editora Plêiade/ FAPESP, 2001. 218p.
HORAK, I. G.; CAMICAS, J. L.; KEIRANS, J. E. The Argasidae, Ixodidae and Nuttalliellidae (Acari: Ixodida): a world list of valid tick names. Experimental and Applied Acarology, v. 28, n. 1/4, p. 27-54, 2002.

KEIRANS, J. E.; DURDEN, L. A. Illustrated key to nymphs of the tick genus Amblyomma (Acari: Ixodidae) found in the United States. Journal of Medical Entomology, v. 35, n. 4, p. 489-495, 1998.

LABRUNA, M. B. et al. Parasitism of domestic swine (Sus scrofa) by Amblyomma ticks (Acari: Ixodidae) on a farm at Monte Negro, Western Amazon, Brazil. Journal of Medical Entomology, v. 39, n. 1, p. 241-243, 2002.

LABRUNA, M. B. et al. Ticks (Acari: Ixodidae) associated with rural dogs in Uruará, eastern Amazon, Brazil. Journal of Medical Entomology, v. 37, n. 5, p. 774-776, 2000.

MARTINS, T. F. et al. Host records for the immature stages of Amblyomma fuscum (Acari: Ixodidae), a South American tick species. Entomological News. (in press).

ROCHA, J. M. Identificaçáo e incidência dos ixodídeos no município de Garanhuns - PE. Belo Horizonte, 1985. 52f. Dissertação (Mestrado) - Universidade Federal de Minas Gerais.

SANTANA, V. L. A. et al. Comparação entre os índices de eficácia obtidos nos tempos de imersão de 5 e 10 minutos em soluçôes acaricidas comerciais à base de deltametrina e cipermetrina em amostras de fêmeas ingurgitadas de Boophilus microplus do estado de Pernambuco, Brasil. Ciência Animal, v. 11, n. 1, p. 17-20, 2001a.

SANTANA, V. L. A. et al. Situação do controle químico do Boophilus na zona da mata e Agreste do Estado de Pernambuco. Ciência Veterinária nos Trópicos, v. 4, n. 2/3, p. 281-290, 2001 b.

SILVA, A. S.; SILVA, M. K.; MONTEIRO, S. G. Parasitismo por Amblyomma triste em gato doméstico. Revista Brasileira de Parasitologia Veterinária, v. 16, n. 2, p. 108-109, 2007.

SILVA, O. A. et al. La leishmaniose viscérale canine dans le Nord-Est du Brésil: aspects épidémiologiques. Bulletin de la Société de Pathologie Exotique, v. 100, n. 1, p. 49-50, 2007.

SILVA, S. F. Identificação das espécies de ixodídeos em eqüídeos no município de Garanhuns (PE). Recife, 1989. 80f. Dissertação (Mestrado) - Universidade Federal Rural de Pernambuco.

SILVA, V. P. R. On climate variability in Northeast of Brazil. Journal of Arid Environments, v. 58, n. 4, p. 575-596, 2004

SUZUKI, E. M.; DAEMON, E.; FACCINI, J. L. H. Efeitos das umidades relativas de 30 e $50 \%$ sobre o desenvolvimento de ovos de Anocentor nitens (Neumman, 1987) (Acari: Ixodidae) expostos por diferentes intervalos de tempo. Revista Brasileira de Zoociências, v. 1, n. 1, p. 69-76, 1999.

YODER, J. A. et al. Developmental profiles in tick water balance with a focus on the new Rocky Mountain spotted fever vector, Rhipicephalus sanguineus. Medical and Veterinary Entomology, v. 20, n. 4, p. 365-372, 2006. 